\title{
Pawnshops in the Perspective of Islamic Law
}

\author{
Rahmat Ilyas
}

\begin{abstract}
Pawnshops in the Perspective of Islamic law. The development of the economy and the business world will always be followed by the development of the need for credit and the provision of credit facilities that always require collateral. This is for the security of the provision of credit in the sense that the loan received will be guaranteed by guarantee. In this context the importance of the guarantee institution lies. Pawn is a guarantee institution that has been very well known in people's lives in their efforts to get funds for various needs. Pawnshops is a state-owned enterprise in Indonesia whose core business is in the field of lending/loan services to the public on the basis of mortgage law. In Indonesia the legal basis of Pawnshop are: the MUI DSN fatwa No. 25 / DSN-MUI / III / 2002 dated June 26, 2002 concerning rahn which states that loans with mortgaged goods as collateral for debt in the form of rahn are permitted; the MUI DSN fatwa No.26 / DSN-MUI / III / 2002 concerning gold pawning; as well as the MUI DSN fatwa No. 68 / DSN-MUI / III / 2008 about rahn Tasjily
\end{abstract}

Keywords: mortagage, Islamic law, the DSN MUI fatwas

\begin{abstract}
Abstrak: Pegadaian dalam Perspektif Hukum Islam. Perkembangan ekonomi dan dunia bisnis akan selalu diikuti oleh perkembangan kebutuhan akan kredit, dan penyediaan fasilitas kredit yang selalu membutuhkan agunan. Hal ini untuk keamanan pemberian kredit dalam arti bahwa piutang pinjaman akan dijamin dengan jaminan. Dalam konteks inilah, pentingnya lembaga penjaminan terletak. Gadai adalah lembaga jaminan yang telah sangat terkenal dalam kehidupan masyarakat dalam upayanya untuk mendapatkan dana untuk berbagai kebutuhan. Pegadaian adalah perusahaan milik negara di Indonesia yang bisnis utamanya adalah di bidang layanan pinjaman / pinjaman kepada publik berdasarkan hukum hipotek. Di Indonesia, dasar hukum Pegadaian adalah: fatwa MUI DSN No. 25 / DSN-MUI / III / 2002 tanggal 26 Juni 2002 tentang Rahn yang menyatakan bahwa pinjaman dengan barang-barang yang digadaikan sebagai jaminan hutang dalam bentuk rahn diizinkan; fatwa MUI DSN No.26 / DSN-MUI / III / 2002 tentang gadai emas; serta fatwa MUI DSN No. 68 / DSN-MUI / III / 2008 tentang rahn Tasjily
\end{abstract}

Kata Kunci: pegadaian, hukum Islam, fatwa DSN MUI

Faculty of Sharia and Islamic Economics, Syaikh Abdurrahman Siddik Bangka Belitung State Islamic Religion Institute. Jl. Raya Petaling KM. 13 Desa Petaling Kec. Mendo Barat Kab. Bangka

E-mail: rahmatilyas82@gmail.com \& mtd_82@yahoo.com 


\section{Introduction}

The development of the economy and the business world will always be followed by the development of the need for credit, and the provision of credit facilities that always require collateral. This is for the security of the provision of credit in the sense that the loan received will be guaranteed by guarantee. In this context, the importance of the guarantee institution lies.

Guarantee institutions are classified as legal fields that are neutral, because they do not have a close relationship with the spiritual life and national culture. In such a legal field, there is no objection to be regulated immediately as the legal regulations relating to the guarantee institution in Indonesia are generally obsolete. Very few regulations have undergone changes since their formation as known in the Civil Code and other special regulations, such as mortgages and Verband credits.

Pawn is a guarantee institution that has been very well known in the life of the community in efforts to get funds for various needs. Pawn is a state-owned enterprise in Indonesia whose core business is in the field of lending/loan services to the public on the basis of mortgage law. ${ }^{1}$

\section{Definition of Pawn}

Pawnshop is the only company in Indonesia that runs a pawn business and alternative funding facilities that have been around for a long time and are well-known to Indonesian people, especially in small cities. The main purpose of the pawnshop business is to overcome a financial problem so that the people who are in need of money are not in the hands of moneylenders or bonded laborers or loan sharks, whose interest is relatively high.

${ }^{1}$ Related to the debate about the concept of the pawn in the Islamic economic system contained in several writings including: Budiman Setyo, 'Kedudukan Gadai Syariah (Rahn) dalam Sistem Hukum Jaminan Indonesia', Jurnal Dinamika Hukum, 10.1 (2010), 21-27 <https://doi.org/10.20884/1.jdh.2010.10.1.133>; Siti Hadijah, M. Pd Drs. Anjuman Zukhri, and S. Pd Kadek Rai Suwena, 'Faktor-Faktor Yang Mempengaruhi Keputusan Nasabah Menggunakan Jasa Pegadaian Syariah Kantor Cabang Pegadaian Syariah (Kcps) Denpasar', Jurnal Pendidikan Ekonomi Undiksha, 5.1 (2015) <https://ejournal.undiksha.ac.id/index.php/JJPE/article/view/5076> [accessed 20 May 2019]; Iwan Setiawan, 'Penerapan Gadai Emas Pada Bank Syariah Perspektif Hukum Ekonomi Islam', al-Daulah: Jurnal Hukum dan Perundangan Islam, 6.1 (2016), 188-213 <https://doi.org/10.15642/ad.2016.6.1.188-213>. 
According to Article 1150 of the Civil Code, a notion of mortgage is a right obtained by a creditor on a movable or non-bodied movable property given to him by a debtor or other person in his name to guarantee a debt, and which gives the creditor authority to repay the goods earlier than other creditors except for the costs of auctioning the item and costs incurred to maintain the object, which costs must take precedence.

Pawn has several basic elements, namely:

1. Pawn is born because of the agreement to hand over the power to the pawn goods to the creditor of pawnshop;

2. The surrender can be done by the debtor or another person in the name of the debtor;

3. The goods that are objects of pawning are only movable goods, both stature, and non-body;

4. The creditor of the pledge holder has the right to make repayment from the pawn of goods before the other creditors.

According to the Financial Services Authority Regulation Number 31/ POJK.05 /2016 Article 1 paragraph 10 concerning Mortgage Businesses, mortgage is a right obtained by a Mortgage Company for a movable property, which is handed over to him by the customer or by his proxy, as collateral for his loan, and which authorizes a Mortgage Company to take out a loan from the item in advance of other creditors, with the exception of the cost of auctioning or selling the item and the cost of rescuing the item issued after the item is delivered as a mortgage, which cost must take precedence. ${ }^{2}$

The pawn in the figh is called Rahn which terminologically is the name of the item that is used as a guarantee of trust. Whereas according to Syara, a pawn means to take a host of assets handed over as collateral in a right but can be taken back as a ransom. ${ }^{3}$ In the book of Figh Islam wa Adillatuhu, a pawn or Rahn is considered as ats-Tsubut and adDawaam which means fixed. While the definition of Rahn in syara terms'

\footnotetext{
${ }^{2}$ Financial Services Authority Regulation, Concerning Venture Business Article 1 Paragraph 10., Number 3i /POJK.05/20i6.

${ }^{3}$ Heri Sudarsono, Sharia Banks and Financial Institutions : Descriptions and Illustrations, 4th edn (Yogyakarta: Econition, 2015), p. 171.
} 
is holding something back because of the right that allows that right to be fulfilled from something. The point is to make al-ain (goods, assets whose goods are concrete, the opposite of ad-dain or debt) which has value according to syara', as watsiiqah (affirmation, collateral) of debt if the goods allow it to be used to pay all or part existing debt. ${ }^{4}$

In general, Rahn is categorized as a charity contract because what is given by the pawner (Rahin ) to the recipient of the pawn (Murtahin) is not an exchange accordingly. What is given to Murtahin by Rahin is a debt, not an exchange for goods pawned. Rahn also includes a contract which is ainiyah in nature, which is said to be complete after handing over the objects that are made into contracts, such as grants, loans, deposits, and qirad. ${ }^{5}$

In Indonesian society, besides the term debt, Pawn is also known as the term of credit in conventional banking and the term financing in Islamic banking. Debt is usually used by the community in the context of lending to other parties. A person who lends his property to another person can be considered to have given a debt to him. The term credit or financing is more widely used by the public in banking transactions and purchases that are not paid in cash. Essentially, between debt and credit or financing is not much different in its meaning in society. ${ }^{6}$

\section{History of Pawn in Indonesia}

The business of pawnshops in Indonesia began in the Dutch colonial era where at that time the task of pawnshops was to help the community to lend money with collateral. At first, this business was carried out by the private sector, but in later developments, this pawnshop business was taken over by the Dutch East Indies government. Then, according to the laws of the contemporary Dutch East Indies governmwnt, it was made a state company with the status of a Pawnshop service. ${ }^{7}$

\footnotetext{
${ }^{4}$ Wahbah Az-Zuhaili, Islamic Figh Wa Adillatuhu (Jakarta: Gema Insani, 2011), Iv, p. 107.

${ }^{5}$ Rachmat Syafe'i, Figh Muamalah (Bandung: Faithful Library, 2001), p. 160.

${ }^{6}$ Rahmat Ilyas, 'Konsep Pembiayaan dalam Perbankan Syari'ah', Jurnal Penelitian, 9.1 (2015) <https://doi.org/10.21043/jupe.v9i1.859>.

7 Cashmere, Banks and Other Financial Institutions (Jakarta: PT. Raja Grafindo Persada, 2010), p. 267.
} 
The History of Pegadaian began when the Dutch Government (VOC) founded Bank Van Leening, a financial institution that provides credit with a mortgage system. This institution was first established in Batavia on August 20, 1746. Pegadaian has changed status several times, namely as a State Company (PN ) since January 1, 1961, then based Government regulations No.7 / 1969 became a Bureau of Company (Perjan), and then based on Government Regulation No.10 / 1990 (which was updated with Government Regulation No.103 / 2000) changed again to become a Public Company (Perum). Then in 2011, again, the change of status occurred, namely from the Public Corporation to the Company as stipulated in Government Regulation (PP) No.51/2011 signed on December 13, 2011. However, the change was effective after the articles of Association were submitted to the authorities on 1 April 2012. ${ }^{8}$

Along with the development of sharia-based products in Indonesia, the pawnshop sector also experienced a growth. Islamic Pawnshop is present in Indonesia by the establishment sharia mortgage services in several cities in Indonesia. Besides that, there are also Islamic banks runing their own Islamic pawnshops. Islamic Pawnshop began operating since 2003. Until October 2015, the number of sharia pawn shops reached 611 outlets throughout Indonesia, consisting of 83 branches and 528 unit offices.?

\section{The Law of Mortgage}

The basis of the implementation of sharia mortgage can be found in the surah Al-Baqarah verse 283:

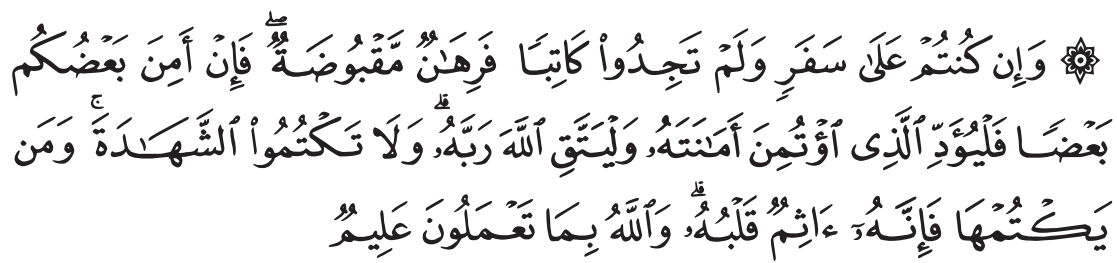

If you are on the way (and you are not in cash) while you are not getting a writer, then there should be items held (by those who owe). But

8 'Pegadaian (perusahaan)', Wikipedia bahasa Indonesia, ensiklopedia bebas, 2019 <https:// id.wikipedia.org/w/index.php?title=Pegadaian_(perusahaan)\&oldid=15055161> [accessed 20 May 2019].

${ }^{9}$ Andri Soemitra, Bank and Islamic Financial Institutions, 2nd edn (Jakarta: Kencana, 2017), p. 400. 
if some of you trust some of the others, then let those who are trusted fulfill their mandate (debt) and let them fear Allah Allah; and do not (the witnesses) hide the testimony. And whoever hides it, surely he is a sinner; and God knows what you do. ${ }^{10}$

This verse explains the cash transactions carried out during the trip where there is no clerk (the bible) who writes them. Therefore, there should be dependents held by the debtor. The dependent goods are held if one another does not believe also as the fulfillment of the principle of prudence. Unless each party trusts and surrenders himself to God, the transaction may be carried out without dependents because the debtor will pay. ${ }^{11}$

The above mentioned paragraph does not stipulate that the dependent goods may only be carried out on the condition of the trip, where the transaction is not a cash and there is no clerk. This paragraph only states that under these circumstances it is justified to use dependent goods. ${ }^{12}$

Collateral is not in the form of writing or witnesses, but trustworthiness. Debt is received by the debtor and the collateral is handed over to the lender. Trust is those who give to those who are given, or who are entrusted, that something given or entrusted to him will be maintained as it should, and give it back at the time the debtor ask for it again. The recipient accepts it on the basis of the trust of the giver and what he receives is accepted as it is and in the future the giver/participant will not ask for more than what the two parties have given or agreed to. ${ }^{13}$

The hadith of the Prophet Muhammad as narrated by al-Bukhari and Muslim from Aisha, RA says;

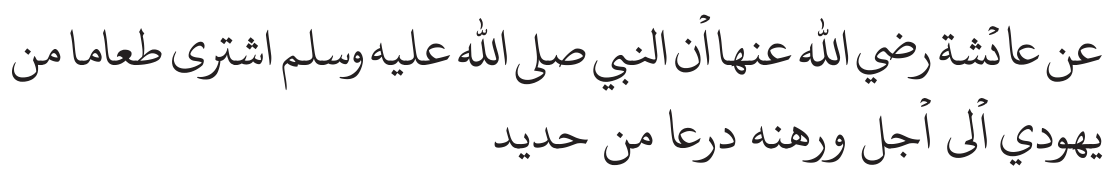

${ }^{10}$ Ministry of Religion of the Republic of Indonesia, Qur'an and Translation (Surabaya: Mekar Surabaya, 2004), p. 60.

${ }^{11}$ Dwi Suwikno, Compilation of Tafsir Verses in Islamic Economic (Yogyakarta: Student Library, 2010), p. 242.

${ }^{12}$ Dwi Suwikno.

${ }^{13}$ M. Quraish Shihab, Tafsir Al-Misbah : Message, Impression, and Harmony of the Qur'an (Jakarta: Lentera Hati, 2002), p. 740. 
"From Aisha Rhadiyallahu Anha, that the Prophet Sallahu alaihi wa Sallam had bought food from a Jew and he pawned armor from iron." (Bukhari-Muslim) ${ }^{14}$

Another hadith also narrated from Anas Ibn Malik RA says;

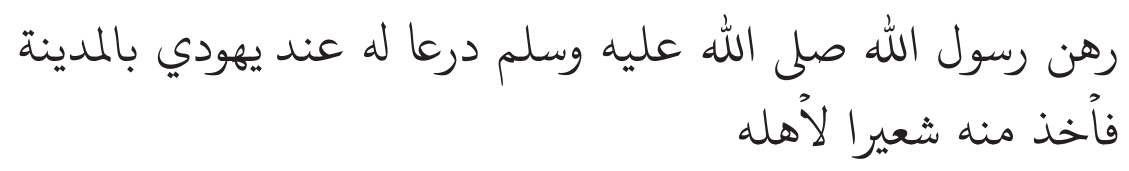

"Rasulullah saw. Pawn his shield to a Jew in adultery to get the wheat he uses to feed his wife"

The majority of ulama agree that ar-Rahn is permissible, both when in the midst of travel, and when settling down. Because the Sunnah explains about the recitation of ar-Rahn absolutely, both when it is in the middle of the journey and while staying. This opinion is different from the opinion of the mujahid and the Zhahiriyyah scholars who accept ar-Rahn only in the event of traveling.

The word of as-Safar (if you are on the way) in verse al- Baqarah 283 only applies on normal habits only; It is not a requirement. Because in the past, it was usually difficult to find a clerk in the middle of the trip. The condition of not finding the clerk also excludes ar-Rahn conditions, because the law may allow ar-Rahn in the Sunnah to be explained absolutely. Therefore the above verse offers a form of watsiqah to the parties which is easy for them when they do not find a clerk who writes down debts or transactions they do. ${ }^{15}$

In Indonesia, the implementation of Islamic mortgage is based on the MUI DSN fatwas, such as : the MUI DSN fatwa No. 25 / DSNMUI / III / 2002 dated June 26, 2002 concerning Rahn stating that loans with mortgaged goods as collateral for debt in the form of Rahn are permitted, the MUI DSN fatwa No.26 / DSN-MUI / III / 2002 concerning gold pawning, and the MUI DSN fatwa No. 68 / DSNMUI / III / 2008 about Rahn Tasjily as well.

\footnotetext{
${ }^{14}$ Mardani, Ayat-Ayat and Islamic Economics Hadith (Jakarta: Rajawali Press, 2012), p. 140.

${ }^{15}$ Wahbah Az-Zuhaili, Iv, p. 109.
} 


\section{Pillars and Mortgage terms}

The pillars of Rahn are:

1. Aqid ( Parties that holds a contract)

2. Shighat

3. Marhun ( Mortgage )

4. Marhun bih, debt secured by the pledge of goods.

The conditions that should be met in mortgage ( Rahn ) are as follows:

1. Requirements for aqid; both people are mindful and must meet the criteria of al-Ahliyah . According to the cleric Syafii, Ahliyah was the person who had been legitimate to buy and sell, namely mindful and mumayyiz, but it was not required to be baligh (mature). Thus, small children who are already mumayyiz, and those who are stupid are allowed to do Rahn under permission from their guardians

2. The requirements of Shighat. The Syafii scholars argue that there are three conditions in Rahn:

a. Valid conditions, such as requiring that the debtor should quickly pay so that the guarantee is not confiscated.

b. Asking something that is not necessary, such as requiring that animals that are used as collateral be given certain foods. Such conditions are nulled, but the contract is valid

c. Terms that damage the contract, such as requiring something that will harm the debtor.

3. Terms of Marhun bih (debt); Syafiiyah and Hanafiyah scholars provide three conditions for Marhun bih

a. The debt is fixed and can be utilized.

b. The debt must be prevalent at the time of contract

c. The debt must be clear and known by Rahin and Murtahin.

4. Terms Marhun, Marhun is a good as collateral by Rahin. The scholars of fiqh agree that the Marhun items should be in the purchase, so that the goods can be sold to meet Murtahin rights. ${ }^{16}$

${ }^{16}$ Rachmat Syafe'i, p. 162-64. 


\section{Pawn Agreement}

A contract is a binding or an agreement between two parties who agree with each other to carry out obligations agreed beforehand. In the contract, the actions and conditions have been determined detailed and specific. If one or both parties are bound in that contract and cannot fulfill his obligations, then one party violates the contract accept sanctions as agreed in the contract. ${ }^{17}$

Basically, there are two forms of pawnshops known in Islamic transactions, namely:

1. Rahn contract. Rahn means holding the borrowers property as collateral for the loan he received until the party who held the guarantee to take back all or part of his debt. With this contract, pawnshops hold movable property as collateral for the customers debt.

2. Tijarah contract, namely the transfer of rights to contract for goods and/or services through the payment of wages lease, without being followed by the transfer of ownership of the goods themselves. Through this contract, it is possible for pawnshops to withdraw leases for the storage of movable property of customers who have made contracts. The operational mechanism of sharia pawnshops through the Rahn contract occurs in the form of the customer submits movable goods and then the pawnshop stores and maintains it in a place provided. The consequences that arise from the storage process are the emergence of costs that include the value of the investment in storage, maintenance costs and the overall process of activities. On this basis, it is justified for pawnshops to charge rental fees to customers in the amount agreed upon by both parties. Sharia pawnshops will get profits only from the cost of leasing the place that is collected not in the form of interest or leased capital calculated from loan money. ${ }^{18}$

Syariah pawn contract must also meet the conditions or requirements attached to them include:

${ }^{17}$ Adiwarman Karim, Islamic Bank : Analysis of Figh and Finance (Jakarta: Rajawali Press, 2009), p. 65.

${ }^{18}$ Andri Soemitra, p. 404. 
1. The contract does not contain the terms imperfect/ falsehood as Murtahin require collateral can be used indefinitely.

2. Marhun bih (loan) is a right that must be returned to the Murtahin and can be repaid with goods. The loan itself must be clear and certain.

3. Marhun (goods) is valuable, clear its size, full legal property of Rahin, not related to the rights of others, and can be submitted both material and benefits, also it can be sold and balance with the loan,

4. The maximum amount of Rahn and the liquidation value of the items in the contract, and the period specified in the procedure.

5. Rahin is burdened with management services for goods in the form of insurance costs, storage costs, security costs, and management and administrative costs.

Regarding the validity of the contract pledge, certain conditions should be met:

1. The existence of lapadz namely the existence of a pawn agreement can be done by oral or written.

2. The existence of the giver and recipient of the pawn with the provision that both the giver and the recipient must have been good and understanding so that they can be considered capable of taking legal action.

3. The existence of the pawned goods; the pawned goods must be present at the time of the pawn agreement and the goods are fully owned by the pledges.

4. The existence of debt is fixed and does not change with additional interest or elements of usury. ${ }^{19}$

\section{Pawn Conditions}

1. Murtahin (recipient of goods) has the right to hold Marhun (property) until all of Rahinss debts (which give up goods) are paid off.

${ }^{19}$ Imamuddin Yuliadi, Islamic Economics; An Introduction (Yogyakarta: Institute for Assessing and Practicing Islam, 2001), p. 140. 
2. Marhun and its benefits belong to Rahin. In principle, Marhun should not be used by Murtahin, except with Rahin's permission, by not reducing the value of Marhun and its use is merely a substitute for maintenance and maintenance costs.

3. The maintenance and the storage of Marhun is basically on Rahin's obligation, but it can also be done by Murtahin, while the cost and maintenance of storage remain on Rahin's obligation.

4. The maintenance and storage costs of Marhun must not be determined based on the loan amount.

5. Marbun sales

a. When due, Murtahin must warn Rahin to pay off his debt immediately.

b. If Rahin still cannot pay off his debt, then Marhun is sold forcibly / executed through sharia-compliant auctions.

c. Marhun's sales results are used to pay off debts, unpaid maintenance and storage costs and sales costs

d. The excess sales proceeds belong to Rahin and his shortcomings are Rahinss obligation. ${ }^{20}$

Technically, the operating mechanism of Syariah pawn is conducted through Islamic banking and sharia pawnshops. Islamic mortgage in its operations can be used as social functions (consumptive), which are urgent, in addition to commercial functions (productive). However, on the level of implementation, there are indications that Islamic pawn is still dominated by commercial productive functions, even if reviewing the background of this mortgage scheme, both implicitly or explicitly siding and aimed at the interests of social functions (daily needs). ${ }^{21}$

In practice, there are several things that may lead to the issue of usury, which is prohibited by Syara'. All that happened when the borrower must provide an additional amount of money or a certain percentage of debt principal. Islam do not allow practice interest rate. Islam allows collecting

${ }^{20}$ MUI DSN, RAHN, Fatwa of the National Sharia Council Number: 25 / DSN-MUI / III / 2002.

${ }^{21}$ Iwan Setiawan. 
service fees ( ujrah) as acceptance and profit. The cost of these services is the most cannot cover all costs incurred in operations.

The difference between pawn in conventional practice and Rahn in sharia practice includes:

1. Rahn in civil law is carried out voluntarily on a moving object; whereas in Islamic law, Rahn applies to all assets, both movable and immovable property.

2. In civil law, liens only apply to movable objects; whereas in Islamic law Rahn applies to all property both movable and immovable property.

3. In Rahn, according to Islamic law, there is no additional term.

4. Pawn according to civil law, carried out through an institution, in Indonesia called pawnshop; Rahn according to Islamic law can be implemented without going through an institution. ${ }^{22}$

Giving debt is an act of virtue to help people who are in a forced situation have no money in a cash. Giving debt requires a guarantee that the debt will be paid by the person who owes it, so that the owner of the money may ask for collateral in the form of valuables. ${ }^{23}$

\section{Law and Consequences of Pawn Agreements (Ar-Rahn)}

Sharia is a provision of Islamic law that regulates human activities which contain commands and prohibitions both concerning the relationship of vertical interaction with God and horizontal interaction with fellow beings. Generally, the sharia principles in Muamalah (sharia transactions) are legally binding for all banking actors and stakeholders who carry out sharia transactions. Morals are norms and ethics that contain moral values in the interaction of fellow beings so that the relationship becomes mutually beneficial, synergistic and harmonious. ${ }^{24}$

${ }^{22}$ Muhammad, Contemporary Society of Financial Institutions (Yogyakarta: UII Press, 2000), p. 90.

${ }^{23}$ Amir Syarifuddin, Outlines of Fiqh (Jakarta: Kencana, 2010), p. 27.

${ }^{24}$ Rahmat Ilyas, 'Kerangka Dasar Penyusunan dan Penyajian Laporan Keuangan Syariah', Asy-Syar'iyyah: Jurnal Ilmu Syariah dan Perbankan Islam, 1.1 (2016), 19-41 <https://doi. org/10.33782/asy.v1i1.603>. 
Legitimate $a r-R a h n$ is a contract that fulfills the ar-Rahn requirements. The binding of the $a r-R a h n$ contract is only one-sided, that is only for ar-Rabin, not for al-Murtahin. Therefore ar-Rahin does not have the right to cancel or annul it, because the position of ar-Rahn is a debt guarantee contract. As for al-Murtahin, he has the right to cancel it at any time, because of the contract of ar-Rahn for his benefit and interests. The contract of ar-Rahn according to all the jurists does not have any legal consequences except with the existence of al-Qabdhu ( al-Marhun has been held and is in the hands of alMurtahin ). Therefore, the price of the goods pawned cannot only be allocated to al-Murtahin or, in other words, he does not have priority rights to the pawned goods and does not have more position than the other debtors except with al-Qabdhu.

If the contract ar-Rahn has been completed with the deposit of the goods pawned to al-Murtahin, there will be legal consequences including:

1. The mortgaged goods are bound by the existing debt.

The general principle, in this case, is that al-Marhun cannot be divided. So if an item pawned as collateral for a debt burden ( alMarhun bih ), all parts of the pawned goods are bound by the debt, as well as the parts of the goods are mortgaged with all parts of the debt. If the portion of the debt that has been lost is due to the release or payment, the goods pawned as a whole remain bound to the remaining debt.

2. The right to arrest al-Marhun (goods pawned)

The right to hold al-Marhun is the consequence of bound with existing debt. Because this attachment is a medium for the debt to be paid from al-marhun or from others. This connection could not arise as desired except by arresting al-Marhun by al-Murtahin. This detention could encourage the person who owed to repay the debt, for fear that the assets he had mortgaged were forcibly sold if he would not pay the debt. ${ }^{25}$

${ }^{25}$ Wahbah Az-Zuhaili, IV, p. 182. 
As for the law of utilizing pledged goods by pawnbrokers and/or pawnbrokers, basically, the pledged goods may not be taken advantage of, either by the owner of the goods or by the pawner, except if the party get permission from other party concerned. The owner of the goods does not have the perfect right anymore that allows him to do legal actions, for example, to accept, to sell, to rent. at any time on his property. Meanwhile, mortgage rights on goods pawn only on the condition or nature of the material that has a value, but not on the use and utilization/collection of results. As the owner of the pledge, he has no right to use the item, but as the owner, if the goods produce the results, the results belong to him. ${ }^{26}$

Based on the above provisions, if the pawned item is a two-wheeled vehicle or in the form of land, for example: both parties are not entitled to use the pledged item without the permission of the owner of the goods. However, it is feared that it could conflict with the provisions in Islam concerning property rights, namely that the property belongs to Allah which is a mandate for the person who owns the property. Because in the pawn agreement it contained the provisions "if the pawner asks to be allowed to use/take advantage of the pledged goods, then the results become joint property. This provision is intended to avoid non-functional property (redundant). ${ }^{27}$

\section{Conclusion}

The pawn in the fiqh is called Rahn which is the name of the item used as a guarantee of trust. Whereas according to Syara 'pawn means to take a host of assets handed over as collateral in a right but can be taken back as a ransom.

Ulama agree that ar-Rahn is permissible, both when in the midst of travel, and when settling down as the Sunnah explains about the recitation of ar-Rahn absolutely, both when it is in the middle of the journey and while staying.

${ }^{26}$ Veithzal Rivai, et al, Bank and Financial Institution Management: Conventional \& Sharia System (Jakarta: Rajawali Press, 2007), p. 1342.

${ }^{27}$ Veithzal Rivai, et al. 
In the implementation of Islamic sharia in Indonesia, which is the legal umbrella for fulfilling sharia principles, it adheres to the MUI DSN fatwa No. 25 / DSN-MUI / III / 2002 dated June 26, 2002 concerning Rahn which states that loans with mortgaged goods as collateral for debt in the form of Rahn are permitted, and MUI DSN fatwa No. 26 / DSN-MUI / III / 2002 concerning gold pawning. In addition, there was also the MUI DSN fatwa No. 68 / DSN-MUI / III / 2008 about Rabn Tasjily.

\section{Bibliography}

Az-Zuhaili, Wahbah, Islamic Figh wa Adillatuhu, Jakarta: Gema Insani, 2011, iv.

Cahsmere, Banks and Other Financial Institutions, Jakarta: PT. Raja Grafindo Persada, 2010.

Financial Services Authority Regulation, Concerning Venture Business Article 1 Paragraph 10., Number 31 /POJK.05/2016.

Hadijah, Siti, M. Pd Drs. Anjuman Zukhri, and S. Pd Kadek Rai Suwena, 'Faktor-Faktor Yang Mempengaruhi Keputusan Nasabah Menggunakan Jasa Pegadaian Syariah Kantor Cabang Pegadaian Syariah (Kcps) DenpasaR', Jurnal Pendidikan Ekonomi Undiksha, 5.1 (2015) <https://ejournal.undiksha.ac.id/index.php/JJPE/article/ view/5076> [accessed 20 May 2019]

Ilyas, Rahmat, 'Kerangka Dasar Penyusunan dan Penyajian Laporan Keuangan Syariah', Asy Syar'iyyah: Jurnal Ilmu Syariah Dan Perbankan Islam, 1.1 (2016), 19-41 <https://doi.org/10.33782/asy.v1i1.603> , 'Konsep Pembiayaan dalam Perbankan Syari'ah', Jurnal Penelitian, 9.1 (2015) <https://doi.org/10.21043/jupe.v9i1.859>

Karim, Adiwarman, Islamic Bank : Analysis of Fiqh and Finance, Jakarta: Rajawali Press, 2009.

Mardani, Ayat-Ayat and Islamic Economics Hadith, Jakarta: Rajawali Press, 2012.

Ministry of Religion of the Republic of Indonesia, Qur'an and Translation, Surabaya: Mekar Surabaya, 2004. 
Muhammad, Contemporary Society of Financial Institutions, Yogyakarta: UII Press, 2000.

MUI DSN, RAHN, Fatwav of the Syari'ah Council No: 25 / DSNMUI / III / 2002

'Pegadaian (perusahaan)', Wikipedia bahasa Indonesia, ensiklopedia bebas, 2019 <https://id.wikipedia.org/w/index.php?title=Pegadaian_ (perusahaan)\&oldid=15055161> [accessed 20 May 2019]

Setiawan, Iwan, 'Penerapan Gadai Emas pada Bank Syariah Perspektif Hukum Ekonomi Islam', al-Daulah: Jurnal Hukum dan Perundangan Islam, 6.1 (2016), 188-213 <https://doi.org/10.15642/ ad.2016.6.1.188-213>

Setyo, Budiman, 'Kedudukan Gadai Syariah (Rahn) dalam Sistem Hukum Jaminan Indonesia', Jurnal Dinamika Hukum, 10.1 (2010), 21-27 <https://doi.org/10.20884/1.jdh.2010.10.1.133>

Shihab, M. Quraish, Tafsir Al-Misbah: Message, Impression and Harmony of the Qur'an, Jakarta: Lentera Hati, 2002.

Soemitra, Andri, Bank and Islamic Financial Institutions, 2nd edn (Jakarta: Kencana, 2017)

Sudarsono, Heri, Sharia Banks and Financial Institutions: Descriptions and Illustrations, 4th edn, Yogyakarta: Econition, 2015.

Suwikno, Dwi, Compilation of Tafisir Verses in Islamic Economic, Yogyakarta: Student Library, 2010.

Syafe'i, Rachmat, Fiqh Muamalah, Bandung: Faithful Library, 2001.

Syarifuddin, Amir, Outlines of Fiqh, Jakarta: Kencana, 2010.

Veithzal Rivai, et al, Bank and Financial Institution Management: Conventional \& Sharia System, Jakarta: Rajawali Press, 2007.

Yuliadi, Imamuddin, Islamic Economics; An Introduction, Yogyakarta: Institute for Assessing and Practicing Islam, 2001. 